\title{
HUBUNGAN KADAR KALSIUM DAN FOSFOR DARAH PADA PENDERITA PENYAKIT GINJAL KRONIK (PGK) DI RUMAH SAKIT GADING PLUIT JAKARTA UTARA
}

\author{
*Ellis Susanti ${ }^{1)}$, Ayu Wulandari ${ }^{1)}$ \\ ${ }^{1}$ Program Studi D III Analis Kesehatan, Fakultas Kesehatan, Universitas Mohammad Husni Thamrin \\ Correspondence author: Ellis Susanti, ellis.241289@gmail.com, Jakarta, Indonesia
}

\begin{abstract}
ABSTRAK
Penyakit ginjal kronik (PGK) adalah suatu proses patofisiologi dengan etiologi beragam yang mengakibatkan penurunan fungsi ginjal secara progresif, dan umumnya berakhir dengan gagal ginjal. Gagal ginjal akut maupun kronis hingga saat ini merupakan penyebab hiperfosfatemia yang paling penting dan hal ini selalu terjadi bila laju filtrasi glomerolus menurun 25 hingga 50\% dari normal. Keadaan hiperfosfatemia merupakan salah satu faktor penyebab terjadinya hipokalsemia. Kenaikan sekresi PTH menstimulasi resorpsi fosfor dan kalsium dari tempat penyimpanan utama kalsium, yaitu tulang. Penelitian ini bertujuan untuk mengetahui hubungan kadar kalsium dan fosfor darah pada penderita PGK di RS Gading Pluit. Penelitian ini menggunakan data sekunder, dari bagian rekam medis pada penderita PGK yang melakukan pemeriksaan kalsium dan fosfor periode Januari 2016 - Juli 2018 dengan total sampel sebanyak 86 data. Hasil dari penelitian ini pada laki-laki sebanyak 52,3\% dan pada perempuan sebanyak 47,7\% mengalami kadar kalsium rendah (hipokalsemia) 65,12\%, kadar normal $32,56 \%$, dan kadar tinggi (hiperkalsemia) 2,33\% dengan nilai rata-rata 7,999 mg/dL. Untuk kadar Fosfor, 1,16\% memiliki kadar fosfor rendah (hipofosfatemia), kadar normal 24,42\%, dan kadar tinggi (hiperfosfatemia) 74,42\% dengan nilai rata-rata $5,923 \mathrm{mg} / \mathrm{dL}$. Setelah dilakukan uji korelasi Pearson didapatkan p-value 0,001 yang menunjukkan Ho ditolak karena nilai tersebut $<$ nilai alpha $(0,05)$ artinya Ada hubungan yang rendah dan berpola negatif artinya semakin besar kadar Kalsium maka Kadar Fosfor akan menurun ataupun sebaliknya $(r=-$ $0,354$ dan $p$-value $=0,001)$.
\end{abstract}

Kata Kunci : Penyakit Ginjal Kronik, Kalium, Fosfor

\section{ABSTRACT}

Chronic kidney disease (PGK) is a pathophysiological process with diverse etiology that results in a progressive decline in renal function, and generally ends in renal failure. Acute and chronic renal failure to date is the most important cause of hyperphosphatemia and this always happens when glomerolus filtration rate decreases 25 to $50 \%$ from normal. The state of hyperphosphatemia is one of the contributing factors to the onocylsemia. The increase in PTH secretion stimulates the resorption of phosphorus and calcium from the main storage place of calcium, namely bone. This research aims to find out the relationship of calcium and blood phosphorus levels in PGK patients at Gading Pluit Hospital. This study used secondary data, from the medical records section of PGK patients who conducted calcium and phosphorus tests from January 2016 to July 2018 with a total sample of 86 data. The results of this study in men were $52.3 \%$ and in women as much as $47.7 \%$ experienced low calcium levels (hypocalcemia) 65.12\%, normal levels 32.56\%, and high levels (hypercalcemia) of 2.33\% with an average value of 7,999 $\mathrm{mg} / \mathrm{dL}$. For Phosphorus levels, $1.16 \%$ had low phosphorus levels (hypophosphatemia), normal levels of $24.42 \%$, and high levels (hyperphosphatemia) of $74.42 \%$ with an average value of 5,923 $\mathrm{mg} / \mathrm{dL}$. After pearson correlation test was obtained p-value 0.001 which showed Ho was rejected because the value $<$ alpha value (0.05) means There is a low and negatively patterned relationship meaning the greater the calcium level then phosphorus levels will decrease or vice versa $(r=-0.354$ and $p$-value $=0.001)$.

Keywords : Chronic Kidney Disease, Potassium, Phosphorus

Open Journal System (OJS): journal.thamrin.ac.id

http://journal.thamrin.ac.id/index.php/anakes/issue/view/33 


\section{PENDAHULUAN}

Penyakit Ginjal Kronik (PGK) merupakan masalah kesehatan yang telah mencakup seluruh masyarakat dunia dan berdampak pada jutaan orang dari seluruh ras dan etnis yang terjadi ketika kondisi fungsi ginjal mengalami gangguan dalam mengeksresikan bahan-bahan yang tidak diperlukan tubuh secara ireversibel dan dalam jangka waktu lama. Insiden dan prevalensi PGK di seluruh dunia meningkat tajam pada 3 dekade terakhir. Prevalensi PGK di Amerika Serikat tahap 1-4 menurut National Health and Nutrition Education Survey (NHANES) antara tahun 1999 dan 2006 adalah 26 juta (13\%) dari sekitar 200 juta penduduk Amerika Serikat yang berusia 20 tahun lebih, dan dari jumlah tersebut, 65,3\% berada pada stadium PGK 3 dan 4 (De Boer et.al., 2011; US Renal Data System, 2012).

Studi epidemiologi klinis menunjukkan bahwa PGK menempati urutan pertama dari semua panyakit ginjal di Indonesia. Hal ini disebabkan karena kurangnya kesadaran individu terhadap deteksi dini PGK. Selain sulit disembuhkan, biaya perawatan dan pengobatannya pun mahal, belum lagi kebanyakan pasien PGK tahap awal tidak menunjukkan gejala klinis yang berarti. Menurut data dari The United States Renal Data System (USRDS) tahun 2009 PGK tahap akhir (GGTA) sering ditemukan dan prevalensinya sekitar 10-13\%. Jumlah penderita di Amerika Serikat mencapai 25 juta orang, dan di Indonesia diperkirakan 12,5\% atau sekitar 18 juta orang (Hamer dan El Nahas, 2006; George dan Ritz, 2009; Suhardjono, 2009).

Pada PGK, biasanya terdapat komplikasi kronik yang meliputi anemia akibat eritropoietin yang tidak adekuat, serta penyakit tulang, biasanya dengan kadar kalsium rendah, fosfat tinggi dan hormon paratinoid tinggi. Peningkatan hormon paratiroid (PTH) bisa terjadi akibat retensi fosfat, yang menyebabkan turunnya kalsium terionisasi. Akibat klinisnya ialah osteoporosis akibat hiperparatiroidisme, osteomalasia akibat kekurangan vitamin D dan kalsifikasi ektopik (David, David, dan Bradley, 2007; O'Callaghan, 2009).

Ketidakseimbangan elektrolit (kalsium dan fosfat) di dalam tubuh akan berlangsung terus menerus dan irreversibel. Keseimbangan kalsium fosfat dipertahankan oleh interaksi antara hormon paratiroid (PTH), vitamin D dan kalsitonin melalui mekanisme complex feedback loops yang bekerja di tulang, ginjal dan usus, dimana PTH bertanggung jawab sebagai pengendali utama. Bila penderita PGK dapat bertahan cukup lama, maka ketidakseimbangan kalsium dan fosfat yang disertai gangguan mineralisasi rangka tak mungkin terelakkan dan biasanya dikenal sebagai ginjal osteodistrofi atau renal bone disease. Gangguan mineralisasi tulang ini membuat tulang memiliki struktur yang lemah dan dapat mengalami fraktur atau perubahan bentuk bila mendapat tekanan. Gangguan mineralisasi tulang yang paling sering ditemukan yaitu osteomalasia (60\%) dan osteitis fibrosa (30\%) (Price dan Wilson, 2013; Pratama, Moeis, dan Mandang, 2014).

Open Journal System (OJS): journal.thamrin.ac.id 
Penelitian yang dilakukan Rohmah Ardelia (2014) pada 59 pasien PGK didapatkan hasil 44,10\% mengalami hiperfosatemia dan 42,2\% mengalami hipokalsemia. Gagal ginjal merupakan penyebab tersering dari hiperfosfatemia. Hiperfosfatemia dapat diakibatkan oleh kurangnya eksresi fosfat melalui urin, asupan fosfat yang berlebihan, atau pelepasan fosfat dari sel. Peningkatan fosfat semakin menurunkan kalsium dengan menyebabkan deposit kalsium fosfat di jaringan yang menstimulasi peningkatan hormon paratiroid dan menyebabkan hiperparatiroid sekunder (O'Callaghan, 2009).

Kadar kalsium dan fosfat dalam serum mempunyai hubungan timbal balik, bila kadar kalsium naik maka kadar fosfat akan turun dan demikian sebaliknya, yang dikenal dengan istilah patoknomonik. Hubungan yang saling mempengaruhi ini berperan dalam mempertahankan produksi campuran kalsium-fosfat dalam jumlah yang konstan, sehingga tidak terjadi endapan kalsiumfosfat dalam sistem vaskuler ataupun jaringan tubuh. Dengan semakin lanjutnya penyakit ginjal, maka hubungan yang saling mempengaruhi antara kalium, kalsium dan fosfat makin lama makin terganggu (Price dan Wilson, 2013). Penelitian yang dilakukan oleh Tri Prasetyorini dan Warida (2013) menunjukkan adanya hubungan yang lemah dan berpola negatif, artinya jika kadar fosfor naik, maka akan diikutin dengan penurunan nilai kalsium, dan demikian sebaliknya.

Berdasarkan hal tersebut maka peneliti ingin mengetahui sejauh mana hubungan dan gambaran kadar kalsium dan fosfor pada penderita Penyakit Ginjal Kronik (PGK) di Rumah Sakit Gading Pluit Jakarta Utara.

\section{METODE PENELITIAN}

Tempat penelitian dilakukan di Instalasi Patologi Klinik Rumah Sakit Gading Pluit dan waktu penelitian pada bulan Mei - Agustus 2018. Populasi pada penelitian ini adalah data pasien yang didiagnosa menderita PGK berdasarkan catatan Rekam Medis periode Januari 2016 - Juli 2018. Sedangkan sampel pada penelitian ini adalah data hasil pemeriksaan kalsium dan fosfor pada penderita PGK di Rumah Sakit Gading Pluit periode Januari 2016 - Juli 2018

Pengumpulan data dilakukan dengan menggunakan data sekunder dari pemeriksaan kadar kalsium darah dan fosfor darah pada pasien PGK dengan cara: Membuat surat permohonan izin pengambilan data pemeriksaan kadar kalsium darah dan kadar fosfor pada pasien PGK ke bagian sekertariat Universitas M.H. Thamrin. Memberi surat permohonan izin pengambilan data pemeriksaan kadar kalsium darah dan kadar fosfor pada pasien PGK ke Rumah Sakit Gading Pluit Jakarta Utara. Menerima surat balasan permohonan izin yang telah disetujui oleh pihak rumah sakit. Mencatat data hasil pemeriksaan kadar kalsium dan kadar fosfor darah pada pasien PGK serta mencatat data-data pendukung lainnya, seperti: usia, dan jenis kelamin pasien. Pengolahan data dilakukan dengan cara perhitungan statistik. Penelitian ini merupakan penetian analitik dengan variabel-variabel berjenis numerik dengan skala ukur setiap variabel adalah rasio, maka hasil analisa menggunakan program 
Statistical Product for Social Science (SPSS) akan disajikan dalam bentuk tabel dan narasi. Data yang diperoleh dalam penelitian dikelompokkan dan diolah dengan uji statistik yaitu distribusi frekuensi, distribusi normalitas, dan korelasi Pearson.

\section{HASIL PENELITIAN DAN PEMBAHASAN}

\section{Hasil Penelitian}

Analisa Univariat

Gambaran Karakteristik Pasien PGK di RS Gading Pluit Jakarta Utara

Tabel 1.

Distribusi Pasien PGK di RS Gading Pluit Jakarta Utara

\begin{tabular}{|c|c|c|}
\hline Jenis Kelamin & Jumlah & Persentase \\
\hline Laki-Laki & 45 & $52,3 \%$ \\
\hline Perempuan & 41 & $47,7 \%$ \\
\hline Total & 86 & $100 \%$ \\
\hline
\end{tabular}

Sumber: Data Rekam Medik RS Gading Pluit Jakarta Utara

Distribusi pasien PGK di RS Gading Pluit Jakarta Utara, sebagian besar berjenis kelamin laki-laki yaitu 45 orang $(52,3 \%)$ dan pasien yang berjenis kelamin perempuan yaitu 41 orang $(47,7 \%)$.

Tabel 2.

Distribusi Usia Pasien PGK di RS Gading Pluit Jakarta Utara

\begin{tabular}{|c|c|c|c|c|c|}
\hline \multirow{2}{*}{\multicolumn{2}{|c|}{ Jenis Kelamin }} & \multicolumn{3}{|c|}{ Usia } & \multirow{3}{*}{$\begin{array}{c}\text { Total } \\
45\end{array}$} \\
\hline & & \multirow{2}{*}{$\frac{<40 \text { Tahun }}{2}$} & \multirow{2}{*}{$\frac{\mathbf{4 0}-\mathbf{6 0} \text { Tahun }}{13}$} & \multirow{2}{*}{$\begin{array}{c}>60 \text { Tahun } \\
30\end{array}$} & \\
\hline & n & & & & \\
\hline LanI-Lan! & $\%$ & $4,44 \%$ & $28,89 \%$ & $66,67 \%$ & $100 \%$ \\
\hline \multirow{2}{*}{ Perempuan } & $\mathrm{n}$ & 4 & 13 & 24 & 41 \\
\hline & $\%$ & $9,76 \%$ & $31,71 \%$ & $58,54 \%$ & $100 \%$ \\
\hline \multirow{2}{*}{ Total } & n & 6 & 26 & 54 & 86 \\
\hline & $\%$ & $6,98 \%$ & $30,23 \%$ & $62,79 \%$ & $100 \%$ \\
\hline
\end{tabular}

Sumber: Data Rekam Medik RS Gading Pluit Jakarta Utara

Berdasarkan hasil analisis mengenai distribusi usia pasien PGK dan berdasarkan jenis kelamin didapatkan bahwa proporsi antara pasien laki-laki dan perempuan hampir sama pada setiap kelompok usia. Hampir tidak terlihat perbedaan antara proporsi pasien laki-laki $(28,89 \%)$ dan perempuan $(31,71 \%)$ pada kelompok usia 40 - 60 tahun. Perbedaan antara pasien laki-laki dan perempuan baru terlihat pada kelompok usia $<40$ tahun dan $>60$ tahun, dimana pada kelompok usia $<40$ tahun proporsi pasien perempuan $(9,76 \%)$ lebih tinggi dibandingkan dengan proporsi pasien laki-laki $(4,44 \%)$ dan pada kelompok usia $>60$ tahun proporsi pasien laki-laki $(66,67 \%)$ lebih tinggi daripada pasien perempuan $(58,54 \%)$. 
Gambaran Nilai Kalsium dan Fosfor pada pasien PGK di RS Gading Pluit Jakarta Utara

Tabel 3.

Distribusi Nilai Kalsium dan Fosfor Pada Pasien PGK di RS Gading Pluit Jakarta Utara

\begin{tabular}{|c|c|c|c|c|c|c|c|}
\hline \multicolumn{2}{|c|}{ Variabel } & \multirow{2}{*}{$\begin{array}{c}\text { Rerata } \\
(\mathbf{m g} / \mathbf{d L})\end{array}$} & \multirow{2}{*}{$\begin{array}{c}\text { Rentang } \\
(\mathbf{m g} / \mathbf{d L})\end{array}$} & $\mathbf{6}$ & $\%$ & $\%$ & $\%$ \\
\hline \multirow{4}{*}{ Kalsium } & LK & 8,0 & $5,8-11,1$ & 66,67 & 31,11 & 2,22 & 100 \\
\cline { 2 - 8 } & PR & 8,0 & $5,2-10,6$ & 63,41 & 34,15 & 2,44 & 100 \\
\cline { 2 - 8 } & Total & 8,0 & $5,8-11,1$ & 65,12 & 32,56 & 2,33 & 100 \\
\hline \multirow{4}{*}{ Fosfor } & LK & 6,1 & $2,5-10,3$ & 0 & 26,67 & 73,33 & 100 \\
\cline { 2 - 8 } & PR & 5,8 & $2,4-10,1$ & 2,44 & 21,95 & 75,61 & 100 \\
\cline { 2 - 8 } & Total & 5,9 & $2,4-10,3$ & 1,16 & 24,42 & 74,42 & 100 \\
\hline
\end{tabular}

Sumber: Data Rekam Medik RS Gading Pluit Jakarta Utara

Distribusi rata-rata nilai Kalsium pada pasien PGK di RS Gading Pluit Jakarta Utara adalah sebesar $8,0 \mathrm{mg} / \mathrm{dL}$. Nilai Kalsium terendah adalah $5,8 \mathrm{mg} / \mathrm{dL}$ dan tertinggi adalah 11,1 mg/dL. Kadar kalsium pasien PGK dengan nilai normal 8,5-10,5 mg/dL didapatkan hasil kurang dari normal sebesar 65,12\%, dan yang lebih dari normal sebesar 2,33\%, sedangkan yang mempunyai nilai normal sebesar 32,56\%.

Distribusi rata-rata nilai Fosfor pada pasien PGK di RS Gading Pluit Jakarta Utara adalah sebesar 5,9 $\mathrm{mg} / \mathrm{dL}$. Nilai Fosfor terendah adalah 2,4 mg/dL dan tertinggi adalah 10,3 mg/dL. Sedangkan kadar fosfor pada pasien PGK dengan nilai normal 2,5- 4,8 mg/dL, didapatkan hasil kurang dari normal sebesar $1,16 \%$, yang lebih dari normal sebesar $74,42 \%$, dan yang mempunyai nilai normal sebesar $24,42 \%$.

\section{Analisa Bivariat}

Sebelum dilakukan analisis bivariat dilakukan pengujian normalitas data dari variabel-variabel terkait yang bertujuan untuk menjadi dasar dalam pemilihan uji yang akan dipilih. Bila hasil pengujian ditemukan data berdistribusi normal maka dalam analisis bivariat dipakai uji Pearson dan bila data tidak berdistribusi normal maka maka dalam analisis bivariat dipakai uji Spearman's (Dahlan, 2014).

Jika nilai sign $>0,05$ maka data dapat dikatakan berdistribusi normal, dan jika nilai sign $<0,05$ maka data dapat dikatakan berdistribusi tidak normal.

Dalam Uji Normalitas didapatkan hasil sign $>0,05$. Sehingga dalam analisis bivariat dipakai uji yang termasuk dalam statistik parametrik yaitu uji korelasi Pearson. 
Tabel 4.

Analisis Hubungan Nilai Kalsium dan Fosfor Pada Pasien PGK di RS Gading Pluit Jakarta Utara

\begin{tabular}{|c|c|c|c|}
\hline Variabel & $\mathbf{r}$ & p-value & $\mathbf{N}$ \\
\hline Kalsium - Fosfor & $-0,354$ & 0,001 & 86 \\
\hline
\end{tabular}

Sumber: Data Rekam Medik RS Gading Pluit Jakarta Utara

Hasil analisis hubungan nilai Kalsium dan Fosfor pada pasien PGK di Rumah Sakit Gading Pluit Jakarta Utara menggunakan analisis korelasi didapatkan nilai koefisien korelasi (r) sebesar -0,354 dan $p$-value $=0,001$. Hal ini menunjukkan hubungan yang rendah dan berpola negatif artinya semakin tinggi nilai Kalsium maka tidak selalu diikuti dengan penurunan nilai Fosfor atau sebaliknya. Hasil uji statistik didapatkan adanya hubungan yang signifikan antara nilai Kalsium dan Fosfor pada pasien PGK di RS Gading Pluit Jakarta Utara ( $p$-value $=0,001 ; \alpha=5 \%$ ). Hasil analisis tersebut dapat dilihat pada tabel 9 .

\section{Pembahasan}

Pada Tabel 1. mengenai gambaran karakteristik Pasien PGK di RS Gading Pluit Jakarta Utara penelitian didapatkan penderita penyakit ginjal kronik berjenis kelamin laki-laki lebih banyak dari pada perempuan $(52,3 \%$ dan $47,7 \%)$. Hasil penelitian ini berbeda dengan penelitian yang dilakukan oleh Nugraheni et.al (2016) menunjukkan bahwa terdapat 54 kasus penyakit ginjal kronis, diantaranya yaitu 22 orang (40,74\%) laki-laki dan 32 orang $(59,26 \%)$ perempuan. Perbedaan hasil uji dapat dikarenakan jumlah data penelitian yang berbeda, ataupun lingkungan dan gaya hidup penderita yang tidak sama. Berbeda dengan hasil penelitian yang dilakukan dengan oleh Triyati et.al. (2008) di RS Cipto Mangunkusumo terhadap 1238 pasien baru terdiagnosis diabetes melitus yang mendapatkan hasil tidak terdapat hubungan secara bermakna antara jenis kelamin dan Penyakit Ginjal Kronik.

Jenis kelamin bukanlah merupakan faktor risiko utama terjadinya Penyakit Ginjal Kronik karena hal ini juga berhubungan dipengaruhi oleh ras, faktor genetik, dan lingkungan. Penyakit Ginjal Kronik merupakan penyakit multifaktorial. Ada beberapa hal yang diduga sebagai faktor risiko terjadinya penyakit ginjal kronik, seperti hipertensi, diabetes melitus, infeksi saluran kemih, riwayat batu saluran kemih, dan obesitas. Penelitian yang dilakukan oleh Chang et.al. (2008) di Rumah sakit Umum Cathay Taiwan menunjukkan bahwa hipertensi dan diabetes melitus merupakan faktor resiko terbanyak penyebab penyakit ginjal kronik. US Renal Data System tahun 2006 juga melaporkan penyebab utama penyakit ginjal kronik di Amerika Serikat adalah diabetes melitus (44,9\%) dan hipertensi (27,2\%) (Abboud dan Herich, 2010). Dari data tersebut dapat terlihat bahwa penyebab utama penyakit ginjal kronik di Indonesia tidak hanya penyakit infeksi. Penyakit non infeksi seperti diabetes melitus dan hipertensi juga telah menjadi faktor risiko utama. Hal ini dikarenakan perubahan gaya hidup dan pola makan di Indonesia yang telah banyak mengadopsi kebiasaan barat.

Open Journal System (OJS): journal.thamrin.ac.id 
Tabel 2. mengenai distribusi usia pasien PGK berdasarkan usia dan jenis kelamin. Usia merupakan faktor risiko penyakit degeneratif yang tidak dapat dihindari. Secara alamiah, semua fungsi organ tubuh termasuk ginjal akan menurun dengan bertambahnya usia (Levey dan Coresh, 2012). Pada penelitian ini, semakin bertambah usia semakin meningkat pula risiko untuk mengalami PGK. Hasil penelitian ini menunjukkan jumlah pasien PGK terbanyak berada pada kelompok usia $>60$ tahun (62,79\%). Pada penelitian yang dilakukan oleh Delima et.al. (2017) pada empat Rumah Sakit di Jakarta ditemukan bahwa kelompok usia 61-86 tahun berisiko 4,51 (95\%CI 1,95 - 10,40) kali dibandingkan kelompok usia 18-30 tahun. Penelitian di Iran juga menunjukkan kecenderungan yang sama (Najafi et.al., 2010). Data dari poliklinik diabetes RSCM menunjukkan fungsi ginjal dengan eLFG $<60 \mathrm{ml} /$ menit menurut CG-BSA juga ditemukan lebih tinggi pada pasien DM baru yang berusia $\geq 60$ tahun $(63 \%)$, dibandingkan pasien berusia $<60$ tahun (34,1\%) (Triyanti et.al., 2008).

Usia yang lebih tua mempunyai risiko PGK yang lebih besar dibanding usia yang lebih muda. Penurunan eLFG merupakan proses "normal aging". Ginjal tidak dapat meregenerasi nefron yang baru, sehingga ketika terjadi kerusakan ginjal, atau proses penuaan terjadi penurunan jumlah nefron. Pada usia 40 tahun jumlah nefron yang berfungsi berkurang sekitar $10 \%$ setiap 10 tahun dan pada usia 80 tahun hanya $40 \%$ nefron yang berfungsi (Roina dan Megawati, 2010). Hasil Baltimore Longitudinal Study of Aging (BLSA), menunjukkan terjadinya penurunan klirens kreatinin rata-rata sebesar $0,75 \mathrm{ml} / \mathrm{min} /$ tahun pada responden tanpa penyakit ginjal atau penyakit penyerta lainnya dari waktu ke waktu seiring dengan bertambahnya usia, sehingga setelah berusia 30 tahun, laju filtrasi akan berkurang $1 \mathrm{ml} \mathrm{min} / 1,73 \mathrm{~m}^{2}$. Namun tidak semua responden mengalami penurunan klirens kreatinin, hal ini karena adanya faktor komorbid yang akan mempercepat penurunan eLFG (Prakash dan O'Hare, 2009). Hasil kohort studi dari Framingham Offspring study pada 2.585 subjek tanpa PGK yang diikuti selama 12 tahun, menyebutkan bahwa penurunan LFG berhubungan dengan usia (OR = 2,36 per 10 tahun peningkatan usia; 95\% CI 2,00-2,78) (Scottich Intercollegiate, 2008).

Tabel 3. membahas tentang Nilai Kalsium dan Fosfor Pada Pasien PGK di RS Gading Pluit. Kadar kalsium pasien PGK di RS Gading Pluit Jakarta Utara dengan nilai normal 8,5-10,5 mg/dL dengan rata-rata $8,0 \mathrm{mg} / \mathrm{dL}$. Berdasarkan nilai normal tersebut pasien dengan hasil kurang dari normal sebesar $65,12 \%$, dan yang lebih dari normal sebesar $2,33 \%$, sedangkan yang mempunyai nilai normal sebesar $32,56 \%$.

Hasil yang diperoleh menunjukkan adanya variasi namun yang paling banyak adalah penderita yang mengalami penurunan kadar kalsium (hipokalsemia). Hipokalsemia terjadi akibat adanya gangguan pengaktifan vitamin D yang mana vitamin D diperlukan untuk merangsang absorpsi kalsium dan fosfat dari usus. Hipokalsemia merangsang kelenjar paratiroid untuk mengeluarkan lebih banyak PTH yang bekerja untuk merangsang reabsorpsi kalsium, meningkatkan ekskresi fosfat dan mengaktifkan vitamin D oleh ginjal. Hipokalsemia dapat juga terjadi akibat menurunnya GFR sampai sekitar 25\% 
dari normal, sehingga menyebabkan hiperfosfatemia, keseimbangan tersebut bergeser ke kanan sehingga kadar kalsium menurun (Prasetyorini dan Warida, 2015).

Penelitian yang dilakukan Yauri, Moeis, dan Pandelaki (2016) juga menunjukkan hasil yang serupa. Hampir semua kalsium di dalam tubuh (99\%) disimpan dalam tulang dan hanya $1 \%$ dalam cairan intraselular, dan $0,1 \%$ dalam cairan ekstrasel. Bila konsentrasi kalsium cairan ekstraselular turun dibawah normal, kelenjar paratiroid akan langsung dirangsang oleh kadar untuk meningkatkan sekresi hormon paratiroid hasil akhir berupaya kehilangan massa tulang. Hormon ini akan langsung bekerja untuk meningkatkan resopsi garam-garam tulang, dan oleh karena itu, melepaskan sejumlah besar kalsium ke dalam cairan ekstraselular, sehingga mengembalikan kadar kalsium ke nilai normal (Brenner dan Lazarus, 2000).

Mengenai kategori Fosfor Pada Pasien PGK di RS Gading Pluit dengan nilai normal 2,5- 4,8 mg/dL, didapatkan hasil kurang dari normal sebesar $1,16 \%$, yang lebih dari normal sebesar $74,42 \%$, dan yang mempunyai nilai normal sebesar $24,42 \%$.

Peningkatan kadar fosfat terjadi akibat penurunan GFR dan jumlah massa ginjal yang fungsinya juga menurun, sehingga akan mengurangi ekskresi maupun fungsi metaboliknya. Hasil penelitian Yauri, Moeis, dan Pandelaki (2016) juga menunjukkan hasil yang serupa dimana pasien PGK terbanyak mengalami peningkatan kadar fosfat dalam tubuhnya (hiperfosfatemia).

Gagal ginjal merupakan penyebab tersering hiperfosfatemia berat. Oleh karena itu PTH meningkatkan eksresi fosfat, maka hipoparatiroidisme dapat menyebabkan hiperfosfatemia (O'Callaghan, 2009). Hal ini menyebabkan turunnya vitamin D aktif dan respons tulang terhadap kelenjar hiperparatiroid sehingga pasien akan berisiko mengalami komplikasi GMT-PGK ataupun gangguan kardiovaskular (Yauri, Moeis, dan Pandelaki, 2016).

Tabel 4. mengenai Hubungan Nilai Kalsium dan Fosfor Pada Pasien PGK di RS Gading Pluit Jakarta Utara, didapatkan nilai koefisien korelasi (r) sebesar $-0,354$ dan $p$-value $=0,001$. Kesimpulan dari hasil tersebut adalah hubungan antara Kalsium dengan Fosfor menunjukkan hubungan yang rendah dan berpola negatif artinya semakin tinggi nilai Kalsium maka tidak selalu diikuti dengan penurunan nilai Fosfor atau sebaliknya. Hasil uji statistik didapatkan adanya hubungan yang signifikan antara kadar Kalsium dengan kadar Fosfor. Pada PGK akan terjadi ketidakseimbangan kalsium dan fosfor anorganik yang disertai dengan gangguan rangka yang disebut dengan osteodistrofi ginjal. Hubungan yang timbal balik ini berperan dalam mempertahankan produksi campuran kalsium-fosfat dalam jumlah yang konstan sehingga tidak terjadi endapan kalsium fosfat dalam sistem vaskuler (Price dan Wilson, 2013).

Open Journal System (OJS): journal.thamrin.ac.id 


\section{SIMPULAN}

Distribusi pasien PGK di RS Gading Pluit Jakarta Utara, dengan jumlah pasien 86 orang, sebagian besar berjenis kelamin laki-laki yaitu 45 orang $(52,3 \%)$, dengan mayoritas usia pasien $>60$ tahun yaitu sebesar 62,79\%. Distribusi rata-rata nilai Kalsium pada pasien PGK di RS Gading Pluit Jakarta Utara adalah sebesar 8,0 mg/dL. Nilai Kalsium terendah adalah 5,8 $\mathrm{mg} / \mathrm{dL}$ dan tertinggi adalah 11,1 mg/dL sedangkan rata-rata nilai Fosfor pada pasien PGK di RS Gading Pluit Jakarta Utara adalah sebesar 5,9 mg/dL. Nilai Fosfor terendah adalah 2,4 mg/dL dan tertinggi adalah 10,3 mg/dL. Sebagian besar pasien PGK di RS Gading Pluit Jakarta Utara mengalami hipokalsemia $(65,12 \%)$ dan hiperfosfatemia (74,42\%). Hubungan antara Kalsium dengan Fosfor pada pasien PGK di RS Gading Pluit Jakarta Utara menunjukkan hubungan yang rendah dan berpola negatif artinya semakin tinggi nilai Kalsium maka tidak selalu diikuti dengan penurunan nilai Fosfor atau sebaliknya $(r=-0,354$ dan p-value $=0,001)$.

\section{UCAPAN TERIMA KASIH}

Penulis mengucapkan terima kasih kepada RS Gading Pluit Jakarta Utara, dan Prodi D III Analis Kesehatan Fakultas Kesehatan Universitas MH Thamrin. dalam penelitian ini.

\section{DAFTAR PUSTAKA}

1. Abboud, H dan W.L. Henrich. 2010. Stage IV Chronic Kidney Disease. N Engl J Med. 362:5665.

2. $\quad$ Almatsier, S. 2009. Prinsip Dasar Ilmu Gizi. Jakarta: PT Gramedia Pustaka Utama.

3. Aziz, M.F., Witjaksono, J. dan Rasjidi, I. 2008. Panduan Pelayanan Medik. Jakarta: EGC.

4. Barla, R. 2010. Studi Senyawa Fosfat dalam Sedimen dan Air menggunakan Teknik Diffusive Gradient in Thin Films (DGT). Jurnal Ilmu Dasar. 11(2):160-166.

5. Brenner, B.M., dan Lazarus, J.M. 2000. Prinsip-prinsip Ilmu Penyakit Dalam Vol. 3 (13th ed). Jakarta: EGC.

6. Brunner dan Suddarth. 2014. Keperawatan Medikal Bedah. Ed.8. Vol.2. Jakarta: EGC.

7. Chang, W.Z., H.T. Chu, C.S. Yang, C.C. Chen. 2008. The Factors of Chronic Kidney Disease: Diabetes, Hypertension, Smoking, Drinking, Betelnut Chewing. Hal. 75-79.

8. Charoenphandhu, N. 2007. Physical Activity and Exercise Affect Intestinal Calcium Absorption: A Perspective Review. J. Sports Sci. Technol. 7(1):171-81.

9. Dahlan, S. 2014. Statistika untuk Kedokteran dan Kesehatan. Jakarta: Ardans.

10. David, R., David, W., dan Bradley, J. 2007. Lecture Notes on Clinical Medicine (6th ed). Jakarta: Erlangga.

11. De Boer, I.H., Rue, T.C., Hall, Y.N., Heagerty, P.J., Weiss, N.S., Himmelfarb, J. 2011. Temporal trends in the prevalence of diabetic kidney disease in the United States. JAMA. 305(24): 2532-2539. 2.

12. Delima, Tjitra, E., Tana, L., Halim, F.S., Ghani, L., et.al. 2017. Faktor Resiko Penyakit Ginjal Kronik : Studi Kasus Kontrol di Empat Rumah Sakit di Jakarta Tahun 2014. Buletin Penelitian Kesehatan. 45(1): 17-26. 
13. Dewayani, R. 2007. Penyakit Jantung Koroner pada Chronic Kidney Disease. J Kardiol Ind. 28:392- 95.

14. Edmund, L. 2010. Kidney Function Tests. Clinical Chemistry and Molecular Diagnosis. 4th ed. America: Elsevier.

15. George, L.B. dan Ritz, E. 2009. Hypertension and Kidney Disease, A Marriage that Should Be Prevented. Kidney International. 75: 449-452.

16. Guyton, A.C. dan Hall, J.E. 2014. Buku Ajar Fisiologi Kedokteran Ed. 12. Jakarta: EGC.

17. Hamer, R.A. dan El Nahas, A.M. 2006. The Burden of Chronic Kidney Disease. Br Med J. 332:563-564.

18. Jane, D.A. 2009. Intensive Dieatary Education Using The Phosphorus System Tool Improve Hyperphosphatemia in Patients with Chronic Kidney Disease. Thesis. Toronto: University of Toronto.

19. Ketut, S. 2009. Gagal Ginjal Kronik. In: Sudoyo AW, Setiyohadi B, Alwi I, Simadibrata M, Setiadi S, penyunting. Buku Ajar Ilmu Penyakit Dalam (5th ed). Jakarta: Interna Publishing.

20. Lang, F. 2013. Ginjal, Keseimbangan Air dan Garam. Dalam: Silbernagl S, Lang F. Teks dan Atlas Berwarna Patofisiologi. Jakarta: EGC.

21. Levey, A.S., dan Coresh, J. 2012. Chronic Kidney Disease. Lancet. 379: 165-180.

22. Najafi I, Attari F, Islami F, Shakeri R, Malekzadeh F, Salahi R, et.al. 2010. Renal function and risk factors of moderate to severe chronic kidney disease in Golestan Province, Northeast of Iran. Plos One. 5(12) (e14216): 1-6.

23. O'Callaghan, C. 2009. Gagal Ginjal Kronik dan Renal Bone Disease. In: At a Glance Sistem Ginjal (3rd ed). Jakarta: Erlangga.

24. Olson, T.R. dan Pawlina, W. 2008. A.D.A.M. Student Atlas of Anatomy. England: Cambridge University Press.

25. Parlindungan, F., Dalimunthe, N.N., Mardia, A.I., dan Sanowara, R. 2013. Penyakit Ginjal dan Dialisis. Medan: USU Press.

26. PERNEFRI. 2011. Konsensus Manajemen Anemia Pada Penyakit Ginjal Kronik. Jakarta: Perhimpunan Nefrologi (PERNEFRI).

27. Prakash, S. dan A.M. O'Hare. 2009. Interaction of Aging and CKD. Semin Nephrol. 29(5) : 497-503.

28. Prasetyorini, T. dan Warida, W. 2015. Hubungan Kadar Kalium, Kalsium, dan Fosfor Anorganik Pada Penderita Gagal Ginjal. Jurnal Ilmu Teknologi Kesehatan (JITek). 3(1).

29. Pratama, A., Moeis, E.S., dan Mandang, V. 2014. Hubungan Produk Ca x P dengan Kadar CTerminal Cross Linking Telopeptide Type I Collagen pada Subjek Penyakit Ginjal Kronik yang Menjalani Hemodialisa Rutin. Jurnal e-Clinic (eCI). 2(3).

30. Price, S.A. dan Wilson, L.M. 2013. Patofisiologi Konsep Klinis Proses-Proses Penyakit. Edisi VI. Jakarta: EGC.

31. Risteli, J., Winter, W.E., Kleerekoper, M., dan Risteli, L. 2015. Disorders of Bone and Mineral Metabolism. In: Burtis CA, Bruns DE, Sawyer BG (eds). Tietz Fundamental of Clinical Chemistry and Molecular Diagnostics, 7th ed. St Louis: Elsevier Saunders.

32. Roina dan Megawati. 2010. Faktor-Faktor Yang Mempengaruhi Laju Filtrasi Glomerulus. Medan: USU Press.

33. Scottish Intercollegiate. 2008. Diagnosis and management of chronic kidney disease. A national clinical guideline. Scottish Intercollegiate Guidelines Network. 3-6.

34. Suhardjono. 2009. Penyakit Ginjal Kronik adalah Suatu Wabah Baru (Global Epidemic) di Seluruh Dunia. Annual Meeting Perhimpunan nefrologi Indonesia.

35. Syamsir, A. dan Hadibroto, I. 2007. Gagal Ginjal. Jakarta: Gramedia Pustaka Utama.

36. Terry, C.L. 2013. Keperawatan Kritis. Ed.1. Yogyakarya: Rapha Publishing.

37. Triyanti, K., Suhardjono, P. Soewondo, H. Shatri. 2008. Renal Function Decrement in Type 2 Diabetes Mellitus Patient in Cipto Mangunkusumo Hospital. Acta Med Indones. 40(4) :192-200.

38. Yauri, L.F., Moeis, E.S., dan Pandelaki, K. 2016. Gambaran Hasil Produk Kalsium dan Fosfor pada Pasien PGK Stadium V di Ruang Hemodialisis RSUP Prof. Dr. R.D. Kandou Manado. Jurnal e-Clinic (eCI). 4(2).

Open Journal System (OJS): journal.thamrin.ac.id 
